\title{
Green Eagle Nation: The Politicization of Sports Journalism in the Post- Independence Nigerian Press - CORRIGENDUM
}

\author{
Lynn Schler and Itamar Dubinsky
}

https://doi.org/10.1017/asr.2020.3, published by Cambridge University Press, 5 May 2020

In the original publication of this article (Schler \& Dubinsky 2020), the name of author Itamar Dubinsky was misspelled. The article has since been corrected.

\section{Reference}

Schler, Lynn, and Itamar Dubinsky. 2020. "Green Eagle Nation: The Politicization of Sports Journalism in the Post-Independence Nigerian Press.” African Studies Review 63 (4): 883-905.

(C) African Studies Association, 2021. This is an Open Access article, distributed under the terms of the Creative Commons Attribution license (http:/ / creativecommons.org/ licenses/by/4.0/), which permits unrestricted re-use, distribution, and reproduction in any medium, provided the original work is properly cited. 